\title{
Physicochemical properties, composition and pollen spectrum of ling heather (Calluna vulgaris (L) Hull) honey produced in Spain
}

\author{
J Serra Bonvehí ${ }^{\star}$, E Granados Tarrés 2 \\ ${ }^{1}$ Research Department, Nutrexpa, SA and Mielso, SA, Lepanto, 410-414, 08025 Barcelona; \\ 2 IRTA, Centre de Cabrils, 08348 Cabrils, Barcelona, Spain
}

(Received 6 December 1991; accepted 7 June 1993)

\begin{abstract}
Summary - The palynological and physicochemical properties of 28 samples of commercially produced Spanish ling heather honey were defined. On the basis of the melissopalynological analysis, 5 samples were excluded as they were of different botanical origin; 101 different pollen types were identified in the remaining samples. The relative richness of pollen from Calluna was between 10$33 \%$. The high incidence of Erica spp pollen (usually $>10 \%$ ), makes ling heather honey characterization difficult. The sugar spectrum showed low percentages of glucose $(25.6 \mathrm{~g} / 100 \mathrm{~g})$, high levels of disaccharides, and traces of sucrose and trisaccharides. Enzymatic activity was higher $(51.89$ units on the Gothe scale) than that found in other unifloral Spanish honeys. The total acidity (45.5 $\mathrm{meq} / \mathrm{kg}$ ) exceeds the legal limit established for honey in the EEC. The mineral elements show a predominance of potassium, sodium and calcium. The different fluidity curves were determined using a 4-speed $(16,40,80$ and $160 \mathrm{rpm})$ concentric cylinder rotary viscometer. The thixotropical behaviour of this honey was determined as the crumbling index at the maximum tangential tension that could be generated by the viscometer used.
\end{abstract}

honey / Calluna vulgaris / pollen analysis / physicochemical properties / Spain

\section{INTRODUCTION}

Although Calluna is found throughout the Iberian peninsula, it is basically predominant in the area where the provinces of Soria and La Rioja meet. There are also the heathers Erica aragonensis Wilk, Erica vagans $\mathrm{L}$, Erica scoparia $\mathrm{L}$ and Erica arborea $L$ spread extensively over the IberoSorian highlands at the NE limit of the central plateau. These highlands consist of the typical European transitional scrubland, where Erica arborea appears next to Erica scoparia, growing together with the maquis type comprising Arbutus, Cistus,

* Present address: Laboratori Agrari (Generalitat de Catalunya), Ctra de Cabrils, s/n, 08348 Cabrils (Barcelona), Spain. 
Genista, Buxus, Viburnum, Lavandula, Ulex, Myrtus, Thymus, elements of Quercetum sessiflorae, Quercetum tozae and, in certain cases, Quercetum ilicis, and in which Calluna features as a principal characteristic (Tarazona Lafarga, 1984; Serra Bonvehi and Mundo Elias, 1988). These communities have the following characteristics: they are very frugal, siliceous and acidulous, they are well adapted to the poor soil conditions of the Ibero-Sorian Highlands, and to a climate which is not especially prone to drought or extreme temperatures. In this area, there are some enclaves where Calluna is predominant, although the other heathers do reappear with varying frequency. Therefore it is interesting to determine the pollen spectrum and examine the influence of the presence of Erica spp on Calluna honey, because they have the same flowering period. There are only a few published studies on the composition and characteristic features of ling heather and heather honey. Of these, the most important are the studies by Pryce-Jones (1936; 1944; 1952; 1953), Louveaux (1966, 1977), Pourtallier and Taliercio (1970), Fitó and Rodriguez (1981), Spettoli et al (1982), Henderson (1984), Accorti et al (1986), Speer and Montag (1986), Persano Oddo et al (1988), and Tan et al (1989), although they only determine a few characteristic features. Most of these studies make note of the fact that ling heather honey has thixotropical properties, which make its extraction by centrifugation impossible. Hence, the need to use a "loosener" on the combs. This study attemps to be more complete, in that, apart from the pollen spectrum, we determine the most common features of the honey, such as: water content; colour; electrical conductivity; sugar spectrum; mineral elements; hydroxymethylfurfural; enzymatic activity; true protein content; viscosity; and crumbling index of the thixotropical structure.

\section{MATERIAL AND METHODS}

Twenty-eight samples of commercially produced ling heather honey were taken over 2 successive years from the stores of 2 commercial entities; 5 of the samples were rejected on the basis of pollen spectra. All samples came from lots destined for sale on the market, and had been collected in 1985 and 1986 in the area where the provinces of Soria and La Rioja meet (Spain). For each of the samples, a questionnaire was filled in with data about its handling by the producer, extraction date, type of bee-hive and nomadic route. The samples were preserved at $0-5^{\circ} \mathrm{C}$ in a cold-storage room and analysed as soon as they arrived in the laboratory.

\section{Melissopalynological analysis}

The analysis was carried out in accordance with the methods of the International Commission of Bee Botany (ICBB) of the International Union of Biological Sciences (IUBS), described by Louveaux et al (1978). The grain count was performed following the method suggested by Vergeron (1964) (1 200 grains counted).

The pollens identified were classified according to their frequency. There were 4 classes of pollen: predominant $(>45 \%)=D$; secondary $(16-45 \%)=\mathrm{S}$; important minor $(3-15 \%)=\mathrm{s}$; minor $(<3 \%)=r$. For the absolute number of pollen grains, there are 5 groups: group $\mid=$ honeys low in pollen ( $P K / 10 \mathrm{~g}<20000)$; group $\mathrm{II}=$ normal honeys (PK/10 g 20 000-100 000); group $\mathrm{III}=$ honeys rich in pollen $(\mathrm{PK} / 10 \mathrm{~g} 100000-$ $500000)$; group IV = honeys extremely rich in pollen (PK/10 g 500 000-1000 000); group $V=$ pressed honeys (PK/10 g > 1000 000).

\section{Physical and chemical analysis}

The sugar spectrum was determined in accordance with Serra Bonvehi and Bosch Callis (1988), on a Sigma 2 gas chromatograph and quantified on a Sigma 15 (Perkin-Elmer) microprocessor.

The electrical conductivity was measured in a solution at $20 \%$ dry weight and $20^{\circ} \mathrm{C}$, in a Crison 
model 332 conductimeter, using continuous flow immersion cells.

The enzymatic activity followed the method of White and Pairent (1959), established by the AOAC (1980), on a 260 Shimadzu UV-visible spectrophotometer at $660 \mathrm{~nm}$.

Humidity was determined following Chataway (1932) and Wedmore (1955), a method established by the FAONWO (1969). We used an Atago model 8326 Abbe-type refractometer.

The colour was determined using tristimulary methodology (Aubert and Gonnet, 1983) on a 260 Shimadzu UV-visible spectrophotometer with a path-length of $1 \mathrm{~cm}$.

The free and lactone acidity was evaluated by the method of White et al (1958), and the $\mathrm{pH}$ was measured in a 10\% solution in an Expandable ion Analyzer EA 920 (Crion Research) pH-metre.

The activity of water in the honey $\left(\mathrm{a}_{\mathrm{w}}\right)$ was determined via a Humidat-IC (Novasina) hygrometer at $20 \pm 0.5^{\circ} \mathrm{C}$.

The nitrogen content (protein + amino acids) was measured according to White et al (1962) on a Bloc Digest using a Dosi-Gen S-511 (Selecta) ( $N \times 6.25)$ automatic distiller. Hydroxymethylfurfural was determined by the method of White (1979).

To determine mineral elements, $5 \mathrm{~g}$ honey was reduced to ashes at $500-550^{\circ} \mathrm{C}$ and dissolved in $2 \mathrm{ml}$ and $2 \mathrm{~N} \mathrm{HCl}$, made up to $50 \mathrm{ml}$ with distilled water at $40^{\circ} \mathrm{C}$, and $\mathrm{Cl}_{3} \mathrm{La}$ and $\mathrm{ClCs}$ were added (Sanui and Pace, 1968; De Ruig, 1986). The $\mathrm{K}, \mathrm{Na}, \mathrm{Mg}, \mathrm{Ca}, \mathrm{Fe}, \mathrm{Zn}, \mathrm{Cr}, \mathrm{Cu}$ and $\mathrm{Pb}$ contents were evaluated using a model 703 atomic absorption spectrophotometer (PerkinElmer). $\mathrm{Pb}$ was determined in $15 \mathrm{~g}$ honey $/ 25 \mathrm{ml}$ distilled water.

The viscosity of the honey at $20-20.5^{\circ} \mathrm{C}$ was determined using a 4-speed $(16,40,80$ and $160 \mathrm{rpm}$ ) concentric cylinder rotary viscometer, type Searle-Couette, model RN, VEB-MLW, Prüfärate, Werk Medingen (Germany). The RN measuring mechanism consisted of a bellshaped rotor and a inner cylinder inside a measuring glass, both of which provide 2 shearing surfaces (rotor diameter, $8.57 \mathrm{~mm}$; glass diameter, $15 \mathrm{~mm}$ ). First the speeds of deformation ( $\S$, $\mathrm{s}^{-1}$ ) were calculated, and, with the results read from the scale on the viscometer, shear stress $\left(\mathrm{s}\right.$, dynes $\left./ \mathrm{cm}^{2}\right)$ and apparent viscosity $(\mathrm{n}, \mathrm{cP})$ were determined. The results are represented graphically by a system of cartesian coordinates $(b, \S)$ to yield the fluidity curve, from which it is possible to work out an equation that describes the rheological behaviour of the fluid under study (Prentice, 1984). The ascendent and descendent values were gradually obtained by varying the rotation speed of the cylinder from the highest to the lowest, and vice-versa. During the deformation speed test, values were taken every $20 \mathrm{~s}$, with the aim of seeing the variation that the apparent viscosity underwent throughout the testing time. With these values, one can determine the crumbling index of the thixotropic structure (B) (De Kée and Turcotte, 1980). For the calculation of $(B)$, the following formula was used:

$$
\mathrm{B}=\frac{n_{2}-n_{1}}{\ln t_{2} / t_{1}}
$$

\section{RESULTS AND DISCUSSION}

Table I shows data from the pollen analysis, and tables II-V give values of chemical and physical parameters for the characterization, and provide estimates of their variability.

Five of the 28 samples studied were rejected because they presented a different botanic origin, being considered multiflower honey in which there was a predominance of Erica spp, Centaurea cyanus, Vicia sp and Eucalyptus sp.

In the 23 samples accepted 101 different pollen types were identified with an average of 40 per sample, which exceeds that of the principle monofloral Spanish

Table I. Pollenic richness, number of pollen types, percentage of Erica ssp and Calluna pollen.

\begin{tabular}{lllrc}
$\begin{array}{l}\text { Sample } \\
\text { no }\end{array}$ & $\begin{array}{l}\text { Pollen } \\
\text { types }\end{array}$ & Groups & $\begin{array}{c}\% \text { pollen } \\
\text { Erica }\end{array}$ & $\begin{array}{c}\text { \% pollen } \\
\text { Calluna }\end{array}$ \\
\hline $\bar{X}$ & 40 & IIIIV & 16 & 17 \\
$V_{\max }$ & 46 & $V$ & 33 & 33 \\
$V_{\min }$ & 33 & III & 2 & 10 \\
\hline
\end{tabular}




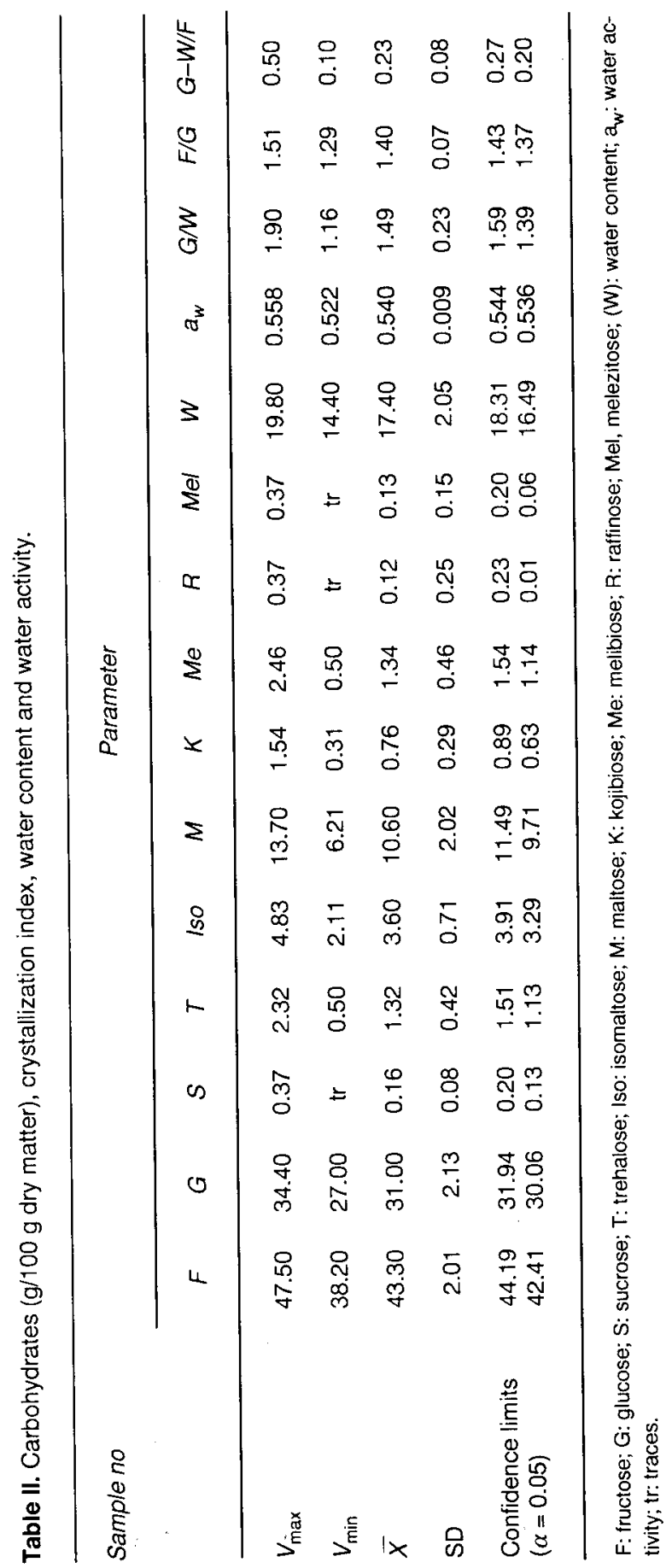




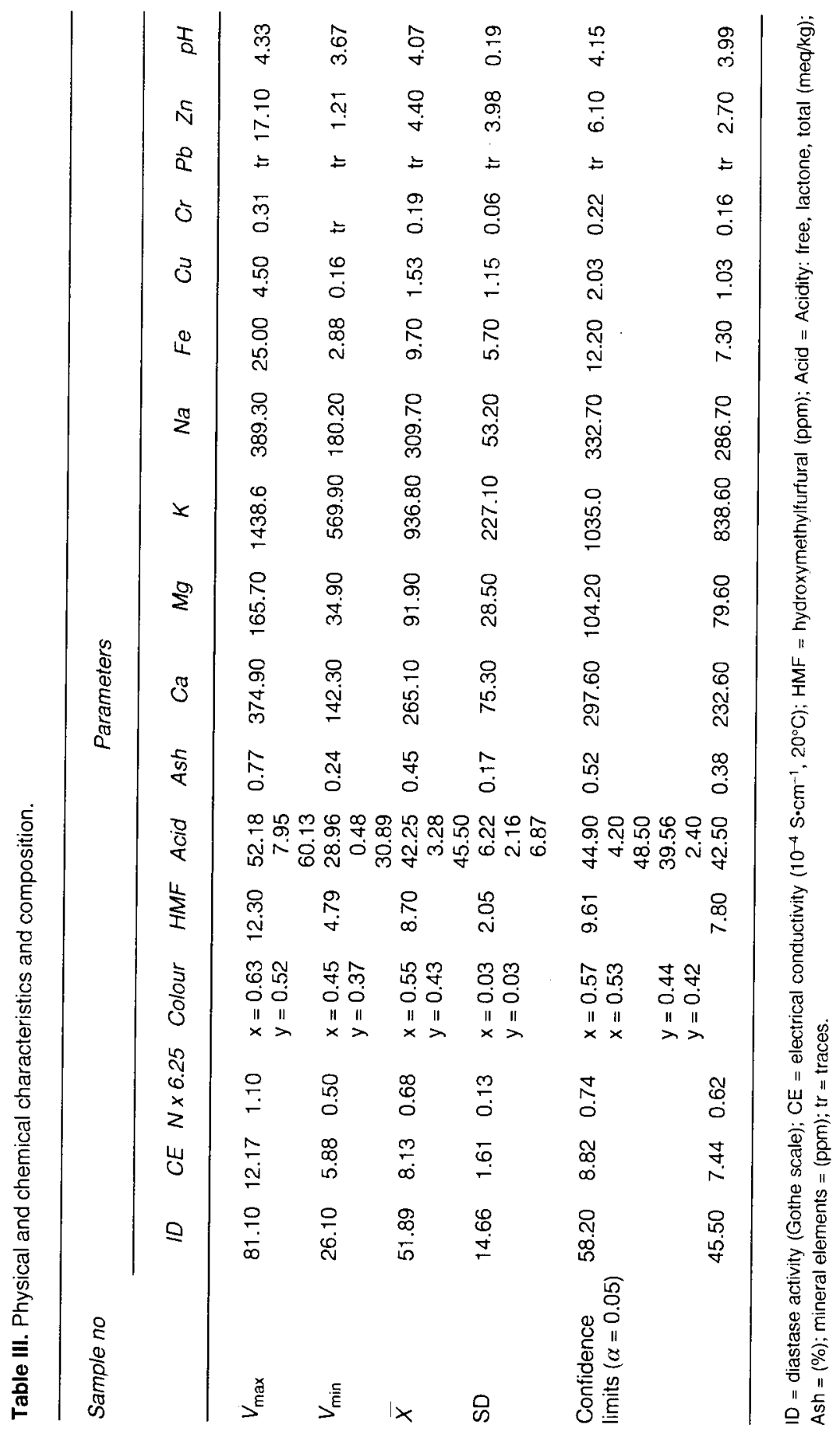


Table IV. Apparent viscosities and applied tangential tensions.

\begin{tabular}{|c|c|c|c|c|c|c|}
\hline \multirow[t]{3}{*}{ Sample no } & \multicolumn{6}{|c|}{ Speed $16,40,80$ and $160 \mathrm{rpm}$ cylinder rotary viscometer } \\
\hline & \multicolumn{3}{|c|}{$\begin{array}{c}\text { Tangential tension } \\
\left(\text { dynes } / \mathrm{cm}^{2}\right)\end{array}$} & \multicolumn{3}{|c|}{$\begin{array}{l}\text { Apparent viscosity } \\
\text { (CP) }\left(20-20.5^{\circ} \mathrm{C}\right)\end{array}$} \\
\hline & $20 \mathrm{~s}$ & $40 s$ & $60 s$ & $20 \mathrm{~s}$ & $40 \mathrm{~s}$ & $60 \mathrm{~s}$ \\
\hline \multirow{4}{*}{$V_{\max }$} & 1176 & 995 & - & 23511 & 19892 & - \\
\hline & 2424 & 2237 & - & 19384 & 17890 & - \\
\hline & 4457 & 4209 & 3838 & 17820 & 16380 & 15346 \\
\hline & 8666 & 8104 & 7861 & 17325 & 16201 & 15516 \\
\hline \multirow{4}{*}{$V_{\min }$} & 248 & 240 & - & 4958 & 4798 & - \\
\hline & 495 & 460 & - & 3960 & 3500 & - \\
\hline & 1310 & 1114 & 990 & 5238 & 4455 & 3960 \\
\hline & 2600 & 2414 & 2221 & 5198 & 4826 & 4455 \\
\hline \multirow{4}{*}{$\bar{x}$} & 584 & 460 & - & 11676 & 9140 & - \\
\hline & 1387 & 1198 & - & $11 \uparrow 72$ & 9724 & - \\
\hline & 2748 & 2468 & 2188 & 11073 & 9963 & 8995 \\
\hline & 5234 & 4907 & 4665 & 10453 & 9878 & 9323 \\
\hline \multirow{4}{*}{ SD } & 217 & 175 & - & 4332 & 3512 & - \\
\hline & 481 & 470 & - & 3869 & 3797 & - \\
\hline & 779 & 735 & 746 & 3153 & 2968 & 2962 \\
\hline & 1334 & 1242 & 1212 & 2663 & 2472 & 2401 \\
\hline
\end{tabular}

honeys (table I) (Serra Bonvehi et al, 1987; Serra Bonvehí, 1988; Serra Bonvehí and Cañas Lloria, 1988). About half of the samples $(52 \%)$ had a minimum of 39 taxons and $30 \%$ had less than 37 taxons. Most of the samples belonged to groups III $(52 \%)$ and IV $(43 \%)$ (table I). The percentage of Calluna pollen was not high $(\bar{X}=$ $17 \%$ ), with only $13 \%$ of the samples being over $25 \%$. As shown in table I, $52 \%$ of the accepted samples contain $16-33 \%$ Erica spp $(\bar{X}=24 \%)$; in the rest of the samples the presence varies from 2 to $16 \%(\bar{X}=$ $8 \%)$. Unfortunately, this high Erica $\mathrm{spp}$ content makes it difficult to identify ling heather honey through a melissopalynological analysis. According to Accorti et al (1986) heather honeys should contain $45 \%$ Erica spp pollen as a minimum. Un- der these circumstances, the only feasible alternative is to limit its presence to such a value that its interactions do not modify the physicochemical characteristics of ling heather honey. Approximately $50 \%$ of the identified taxons appear in forms as important minor (s) and minor pollen ( $r$ ). As dominant pollen (D), only Eucalyptus sp was detected, with Calluna vulgaris and Erica spp as secondary (S). Onobrychis viciifolia and Medicago sativa stand out among the forms of pollen belonging to cultivated plants. Four taxons were outstanding in their different frequencies (Eucalyptus $s p$, Citrus sp, Helianthus annuus and Echium $\mathrm{sp})$ although they do not belong to the phytosociological communities of the collection area, appearing as floral remains from other zones in Spain that find their way to Callu- 
Table V. Crumbling index of the thixotropical structure (B).

\begin{tabular}{|c|c|c|c|}
\hline \multirow[t]{3}{*}{$\begin{array}{l}\text { Sample } \\
\text { no }\end{array}$} & \multicolumn{3}{|c|}{$\begin{array}{c}\text { Speed } 160 \mathrm{rpm} \\
\text { cylinder rotary viscometer }\end{array}$} \\
\hline & \multicolumn{2}{|c|}{ Apparent viscosity } & \multirow{2}{*}{$\begin{array}{l}\text { Crumbling index } \\
\text { (B) }\end{array}$} \\
\hline & $20 \mathrm{~s}$ & $60 \mathrm{~s}$ & \\
\hline 01 & 10148 & 9158 & 330.00 \\
\hline 02 & 10643 & 8374 & 756.30 \\
\hline 03 & 17325 & 15716 & 536.30 \\
\hline 04 & 11261 & 10148 & 371.00 \\
\hline 05 & 11145 & 10096 & 350.00 \\
\hline 06 & 9652 & 8663 & 329.70 \\
\hline 07 & 8178 & 7549 & 209.70 \\
\hline 08 & 10643 & 9405 & 412.70 \\
\hline 09 & 11138 & 9900 & 412.70 \\
\hline 10 & 7625 & 6311 & 438.00 \\
\hline 11 & 10024 & 9281 & 247.70 \\
\hline 12 & 13365 & 10390 & 991.70 \\
\hline 13 & 11138 & 9034 & 701.30 \\
\hline 14 & 8663 & 8168 & 165.00 \\
\hline 15 & 12499 & 12128 & 123.70 \\
\hline 16 & 11138 & 10766 & 123.70 \\
\hline 17 & 5198 & 4455 & 247.70 \\
\hline 18 & 5940 & 5475 & 155.00 \\
\hline 19 & 9404 & 8956 & 149.30 \\
\hline 20 & 12004 & 10024 & 660.00 \\
\hline 21 & 10643 & 10024 & 206.30 \\
\hline 22 & 14726 & 13118 & 536.00 \\
\hline 23 & 7920 & 7278 & 214.00 \\
\hline 24 * & 10420 & 10397 & 7.00 \\
\hline $25^{*}$ & 7809 & 7814 & - \\
\hline $26^{*}$ & 12400 & 12392 & 2.77 \\
\hline $27^{*}$ & 6823 & 6817 & 2.00 \\
\hline $28^{*}$ & 8034 & 8047 & - \\
\hline
\end{tabular}

Viscosity and crumbling index: CP $\left(20-20.5^{\circ} \mathrm{C}\right)$; * samples refused based on their pollen spectra.

na. Among the most characteristic forms identified in this honey were spontaneous and subspontaneous adventitious plants, coming from other crops such as Ranunculaceae, Umbelliferae and Rumex sp.

Pollen forms that were not identified with certainty as belonging to a particular species or genus were grouped under what appear to be the most frequent forms (type Achillea, type Carduus, type C (Centaurea cyanus), type $\mathrm{H}$ (Helianthus annuus), type $\mathrm{R} 22-25 \mu$ (Brassica $\mathrm{sp}$ ), or per group (Prunus Gr, Pyrus Gr).

The taxons most frequently detected in at least $50 \%$ of the samples were: Calluna vulgaris (100\%); Erica spp (Erica aragonensis, Erica vagans, Erica scoparia) $(100 \%)$; Quercus sp (100\%); Salix sp (100\%); Rubus ulmifolius (100\%); Cistus sp (96\%); Cruciferae type R 22-25 $\mu$ (Brassica sp) (96\%); Hypecoum imberbe (96\%); Thymus sp (96\%); Trifolium repens (96\%); Lavandula sp (96\%); Melitotus sp (91\%); type Campanula (78\%); Ligustrum sp (78\%); type Ge nista $(78 \%)$; Lotus sp (78\%); Onobrychis viciifolia $(78 \%)$; Centaurea cyanus $(74 \%)$; Prunus Gr (74\%); Helianthemum sp (70\%); type Carduus (65\%); Taraxacum officinale (61\%); Hypericum sp (61\%); Satureia montana (57\%); type Vicia (57\%); and Castanea sativa $(48 \%)$. All the plants detected were also nectariferous, with exception of Caryophyllaceae, Quercus sp, Cistaceae, Pinaceae, Cupressaceae, Gramineae, Papaver rhoeas, Rumex sp and Ulmaceae.

As table II shows, ling heather honey presented lower percentages of glucose, similar to fructose, isomaltose, kojibiose and melibiose, with the presence of maltose standing out as significantly different $(P=0.01)$ from other unifloral honeys (Espada Herrero, 1984; Accorti et al, 1986; Serra Bonvehí et al, 1987; Serra Bonvehi, 1988; Bogdanov and Baumann, 1988; Serra Bonvehi and Cañas Lloria, 1988; Sabatini et al, 1989). The trisaccharide, sucrose and $F / G$ index results coincide with findings of Pourtallier and Taliercio (1970) and Mateo Castro and Bosch Reig (1984). The $F / G$ index and the respective interval (1.29-1.51) allow for a clear differentiation from Erica spp honey 0.95-1.29 (Espada Herrero, 1984); 0.95-1.25 (Accorti et al, 1986); 0.99-1.25 (Sabatini et al, 1989). 
The electrical conductivity gave an average value of $8.13 \times 10^{-4} \mathrm{~S} \cdot \mathrm{cm}^{-1}$, placing it between flower honey and honeydew, as reported by Pourtallier and Taliercio (1970) (table III).

Ling heather honey presented high levels of diastasic activity, with only $13 \%$ of the samples giving values of less than 40 Gothe units. However, as heather honeys have low levels of diastasic activity, with average values recorded at about 10 Gothe units (Accorti et al, 1986), it could be possible for this parameter to be used as a differentiating element between the 2 honeys.

The average water content value came out at $17.40 \%$. However, $43 \%$ of the samples had humidity values over $19 \%$. The samples collected in 1985 had an average humidity of $15.70 \%$. The same was not true for samples of year 1986, which reflected an average content of $19.31 \%$, which we attribute to different climatic conditions prevailing in the 2 years of collection. The colour was very similar to Erica spp honey and the honeydew of Quercus sp (Rodriguez López, 1983; Accorti et al, 1986), having an average value of $\bar{x}=$ 0.55 (table III), which corresponds to the results of Aubert and Gonnet (1983). There were no indications of fermentation in any of the samples, and the values of activity of water $\left(a_{w}\right)$ were less than 0.70 (table II), which makes the growth of yeasts impossible (Alcalá Aiguilera, 1977). The results in table III evidence the existence of high acidities, exceeding the legal limits (Boe, 1983). These values are essentially consequences of the percentages of gluconic acid and gluconolactone which may be present in the honey (Hadorn and Zürcher, 1963). The $\mathrm{pH}$ values are similar to those detected by Pourtallier and Taliercio (1970). The $N \times 6.25$ content oscillates between 0.50 and $1.10 \%$, with an average content of $0.68 \%$ (table III), which clearly differentiates the samples from the 5 re- fused samples and in general from other honeys, which present average values of $0.17 \%$ (White et al, 1962). The hydroxymethylfurfural values obtained (HMF) are typical of unprocessed honeys, with only 6 samples $(26 \%)$ giving values higher than 10 ppm.

Ashing gave an average mineral content of $0.45 \%$, which is similar to other heather honeys (Espada Herrero, 1984; Accorti et al, 1986). The presence of 9 chemical elements was determined (table III), with a net predominance of $\mathrm{K}$ and $\mathrm{Na}$ ( $77 \%$ of the total), followed by $\mathrm{Ca}(16 \%)$, $\mathrm{Mg}, \mathrm{Fe}, \mathrm{Cu}, \mathrm{Cr}$ and $\mathrm{Zn}$. With respect to other unifloral honeys studied (Serra Bonvehi et al, 1987; Serra Bonvehi, 1988; Serra Bonvehi and Cañas Lloria, 1988), $\mathrm{K}$ was detected in larger proportions, without becoming useful as a differentiating element $(P=0.05)$. Although most honeys behave like Newtonian liquids, ling heather honey is more like a non-Newtonian liquid. If the gradient of deformation is maintained as constant (\$), the tangential tension ( $\mathrm{\beta}$ ) and the viscosity $(n)$ diminish with the time (table IV). This phenomenon is known as thixotropy, which, in ling heather honey, we may attribute to the presence of protein (Pryce-Jones, 1953). In contrast, the rejected samples did not show thixotropy, demonstrating a Newtonian behaviour between tangential tension, apparent viscosity and measuring time. Passage from a gel-sol-gel stage was relatively rapid. Having agitated the honey for 5 minutes, we noticed a progressive decrease in viscosity. Once agitation had ceased, the honey did not completely recover its gel state, but behaved as if it was a non-Newtonian fluid. So long as ling heather honey is not subject to thermal treatment above $70^{\circ} \mathrm{C}$ (Lavie and Gonnet, 1970), thixotropy will be one of the best parameters for its characterization. This may be described by a rheogram, so long as we fix the variables that operate on the measurements in the fol- 
lowing ways: through the ascending and descending curves of the rheogram; by the areas of the fluidity curves, in which the thixotropy is proportional to the area; and via the positioning of the fluidity curve. All of these require the use of expensive apparatus, and so we used a simpler SearleCouette viscosimeter. The different fluidity curves were determined at different speeds with different values of $(\S)$, as constant throughout the measurement stage. Table IV shows the apparent viscosities and the applied tangential tensions.

Table $\mathrm{V}$ illustrates the different values of the crumbling index of the thixotropic structure $(B)$; the data obtained is best described by Burgers model (Scott-Blair, 1970). To establish the smallest thixotropic variation that ling heather honey should require, we determined the crumbling index at the maximum tangential tension that could be generated by the viscosimeter used (table $\mathrm{V}$ ). These data may vary a great deal, for example, Pourtallier and Taliercio (1970) gave a value of $40 \mathrm{cP}$, by applying a cylinder rotation speed of $1 \mathrm{rpm}$. To demonstrate the thixotropical behaviour of our honey, and therefore typify it as a uniflower ling heather honey, a variation in the crumbling index of a minimum of 120 $\mathrm{CP}$ at $20-20.5^{\circ} \mathrm{C}$ was necessary when the corresponding tangential tensions were applied at a rotation speed of the cylinder of $160 \mathrm{rpm}$ for $60 \mathrm{~s}$.

\footnotetext{
Résumé - Propriétés physicochimiques, composition et spectre pollinique du miel de callune (Calluna vulgaris (L) Hull) produit en Espagne. Les caractéristiques polliniques et physicochimiques de 28 échantillons de miels de callune du commerce produits en Espagne ont été étudiées. Sur la base de l'analyse mélissopalynologique (méthodes de I'UISB, Louveaux et al, 1978), 5 échantillons (18\%) ont été éliminés pour avoir une origine bo-
}

tanique différente. Dans les autres échantillons, 101 types polliniques ont été identifiés, avec une moyenne de 40 par échantillon (tableau I). La teneur en pollen est élevée (100 000 à $500000 \mathrm{PK} 10 \mathrm{~g})$. La richesse relative en pollen de Calluna se situe entre 10 et $33 \%$ (tableau I). La forte présence de pollens du genre Erica (en général $>10 \%$ ) rend la caractérisation du miel de callune difficile. Le spectre des sucres présente de faibles pourcentages de glucose $(25,6 \mathrm{~g} / 100 \mathrm{~g})$, des teneurs élevées en disaccharides et des traces de saccharose et de trisaccharides (tableau II). L'activité enzymatique $(51,89$ unités sur l'échelle de Gothe) est plus forte que dans les autres miels monofloraux espagnols. L'acidité totale $(45,5 \mathrm{meq} / \mathrm{kg})$ dépasse la limite légale établie par la CEE pour les miels. II n'y a pas de signes de fermentation et l'activité de l'eau $\mathrm{a}_{\mathrm{w}}$ est $<0.70$. L'analyse minérale montre une prédominance du potassium, du sodium et du calcium. Les diverses courbes de fluidité ont été déterminées à l'aide d'un viscosimètre rotatif à cylindre concentrique aux 4 vitesses suivantes: $16,40,80$ et $160 \mathrm{rpm}$ (tableau IV). Le comportement thixotrope du miel de callune a été déterminé par l'indice de désagrégation (crumbling index, De Kée and Turcotte, 1980) calculé à la tension tangentielle maximum produite par le viscosimètre utilisé (tableau V).

miel / Calluna / caractéristique physicochimique / analyse pollinique / Espagne

\section{Zusammenfassung - Zusammenset- zung, physikalisch-chemische Eigen- schaften und Pollenspektrum im spani- schen Heidehonig (Calluna vulgaris L).} Pollenspektrum und physikalischchemische Eingeschaften von 28 Heidehonigproben kommerzieller spanischer Honigerzeuger wurden analysiert. Nach der melissopalynologischen Analyse (Methodik der UISB, Louveaux et al, 1978) 
waren 5 Proben abweichender botanischer Herkunft und wurden zurückgewiesen. In den übrigen Proben wurden 101 Pollenarten gefunden, im Durchschnitt enthielt eine Probe 40 verschiedene Pollenarten (Tabelle I). Der Pollengehalt war hoch (100 000-500 000 PK/10 g). Der relative Anteil an Calluna Pollen betrug zwischen 10 und $33 \%$ (Tabelle 1), und der hohe Anteil an Erica spp (> 10\% im allgemeinen) Pollen stellt ein Problem für die Charakterisierung dar. Das Zuckerspektrum zeigte hohe Anteile an Disacchariden, geringen Gehalt von Glukose $(25,6 \mathrm{~g} / 100 \mathrm{~g})$, und Spuren von Saccharose und Trisacchariden (Tabelle II). Die enzymatische Aktivität (Gothe-Zahl 51.9) war höher als in anderen spanischen unifloralen Honigen. Der durchschnittliche Säuregrad (45.5 meq $/ \mathrm{kg}$ ) lag höher als die von der EEG für Honig erlaubten Grenzen. An mineralischen Bestandteilen überwogen $\mathrm{Na}$ trium-, Kalium- und Kalziumsalze. Es gab keine Gärungsanzeichen und die Wasseraktivität, $a_{w}$, war $<0.70$. Das thixotropische Verhalten wurde mit einem Viskosimeter bei 4 Umdrehungsgeschwindigkeiten $(16,40,80$ und $160 \mathrm{rpm})$ des Zylinders charakterisiert (Tabelle IV, V).

\section{Honig / Calluna / physikalisch- chemische Eigenschaft / Pollenanaly- se / Spanien}

\section{REFERENCES}

Accorti M, Persano Oddo L, Piazza MG, Sabatini $A G$ (1986) Schede di caratterizzazione della principali qualità di miele italiano. Apicultura 2, appendix, $36 \mathrm{pp}$

Alcalá Aguilera M (1977) Actividad del agua de la miel y crecimiento de microorganismos osmotolerantes. Trab Cientif, Univ Córdoba, Spain, No 20

Association of Official Analytical Chemists (AOAC) (1980) Official methods of analysis. 14th Sect No 31162, Arlington, VA, USA
Aubert S, Gonnet M (1983) Mesure de la couleur des miels. Apidologie 14, 105-118

Bogdanov S, Baumann E (1988) Bestimmung von Honigzuckern mit HPLC. Mitt Geb Lebensmittelunters Hyg 79, 198-206

BOE (Boletin Oficial Del Estado) (1983) Normas de calidad. Miel destinada al mercado interior. BOE No 193, Madrid, Spain, 2045-2047

Chataway HD (1932) The determination of moisture in honey. Can J Res 6, 532-547

De Kée D, Turcotte G (1980) Viscosity of biomaterials. Chem Eng Commun 6, 273-282

De Ruig WG (1986) Atomic absorption spectrophotometric determination of calcium, copper, iron, magnesium, manganese, potassium, sodium and zinc in animal feeding stuffs: interlaboratory collaborative studies. $J$ Assoc Off Anal Chem 69, 1009-1013

Espada Herrero T (1984) Composición y propiedades físicoquímicas de la miel de brezo ( $E r$ ica arborea) producida en Catalunya. Proc 2nd Nat Congr Apic, Gijón, Fundación Principado de Asturias, 327-333

FAO/WHO (1969) Commission du Codex Alimentarius. Norme régionale européenne recommandée pour le miel. CAC/RS 12. Reprinted in: Bee World (1970) 51, 79-91

Fitó A, Rodriguez C (1981) Propiedades réológicas de algunas mieles españolas. I. Simp Inter Apic Transhumante, Valencia, Apimondia, 108-113

Hadorn H, Zürcher K (1963) Formozahl von Honig. Gleichzeitige Bestimmung von Formozahl, $\mathrm{pH}$, freier Säure und Lactongehalt in Honig. Mitt Geb Lebensmittelunters Hyg 54, 304-321

Henderson CE (1984) Some unusual properties of honey: thixotropy and dilatancy. Am Bee J 124, 599-601

Lavie P, Gonnet M (1970) La stabilisation du miel de Callune au moyen d'un traitement thermique. Apidologie 2, 143-155

Louveaux J (1966) Essai de caractérisation des miels de Callune (Calluna vulgaris Salisb). Ann Abeille 9, 351-358

Louveaux J (1977) Les bruyères et leur miel. Bull Tech Apic 4, 31-36

Louveaux J, Maurizio A, Vorwohl G (1978) Methods of melissopalynology. Bee World $59,139-157$ 
Mateo Castro R, Bosch Reig F (1984) Estudio de la composición glucídica de algunos tipos de mieles monoflorales comerciales españolas. Proc 2nd Nat Congr Apic, Gijón, Fundación Principado de Asturias, 358-369

Persano Oddo L, Piazza MG, Accorti M (1988) Diagnosis of unifloral honeys. I. Present knowledge and problems. Apicultura 4, 1-11

Pourtallier J, Taliercio $Y$ (1970) Les caractéristiques physico-chimiques des miels en fonction de leur origine florale. I. Application à un project de normes pour les grandes variétés de miels. Bull Apic Doc Sci Techn Inform 13, 58-68

Prentice JH (1984) Measurements in the rheology of foodstuffs. Elsevier Appl Sci Publ Ltd, Barking, UK

Pryce-Jones J (1936) Thixotropy and elasticrecoil in heather honey. Bee World 17, 89

Pryce-Jones J (1944) Thixotropy in ling heather. Scot Beekeep 20, 118-131

Pryce-Jones J (1952) Studies in thixotropy. Kolloid $Z 129,96-122$

Pryce-Jones J (1953) The rheology of honey. In: Foodstuffs, their plasticity, fluidity and consistency (S Blair, ed) North-Holland Publ Co, Amsterdam, 148-176

Rodriguez López C (1983) Determinación espectrofotométrica del color de las mieles. Doctoral thesis University Polytechnic of $\mathrm{Va}$ lencia, Spain

Sabatini AG, Persano Oddo L, Piazza MG, Accorti M, Nanetti A (1989) Glucide spectrum in the main Italian uniflora honeys. I. Fructose and glucose. Apicultura 5, 35-46

Sanui H, Pace N (1968) Chemical ionization interferences in the atomic absorption spectrophotometric measurement of sodium, potassium, rubidium and cesium. Anal Biochem 25, 330-346

Scott-Blair GW (1970) Principles of rheology. Acad Press, London

Serra Bonvehí J (1988) Propriétés physicochimique, composition et spectre pollinique des miels de Lavandula latifolia Med produits en Espagne. Sci Aliments 8, 295-307

Serra Bonvehí J, Gomez Pajuelo A, Gonell Galindo $F$ (1987) Composición propiedades físico-químicas y espectro polínico de algu- as mieles monotlorales de España. Alimentaria $185,61-84$

Serra Bonvehí J, Bosch Callis J (1988) Determinación de azúcares de la miel mediante cromatografía de gas. An Quím 85(B), 38-46

Serra Bonvehí J, Cañas Lloria S (1988) Caratteristiche fisico-chimiche, composizione e spettro pollinico del miele di eucalipto (Eucalyptus sp) prodotto in Spagna. Apicoltura 4, 59. 81

Serra Bonvehí, J Mundo Elias P (1988) Study of pollen spectrum of ling heather, Calluna vulgaris $\mathrm{L}$ (Hull), honeys produced in Spain. J Apic Res 27, 169-174

Speer K, Montag A (1986) Verteilung freier Aminosäuren in Honigen unter besonderer Berücksichtigung der deutschen und der französischen Heidehonige. Dtsch Lebensm Rundsch 82, 248-253

Spettoli P, Bottacin A, Pescia P, Girolami V (1982) Caratteristiche fisico-chimiche di mieli di Erica arborea toscani. Ind Alim 21, 617620

Tan ST, Wilkins AL, Holland PT (1989) Extracts from New Zealand unifloral honeys. 2. De graded carotenoids and other substances from heather honey. J Agric Food Chem 37 , 1217-1221

Tarazona Lafarga MT (1984) Estudio florístico, ecológico y fitosociológico de los matorrales del sector Ibérico-Soriano. Doctoral Thesis, University of Madrid, Spain

Vergeron $P$ (1964) Interpretation statistique des résultats en matière d'analyse pollinique des miels. Ann Abeille 7, 349-364

Wedmore EB (1955) The accurate determination of the water content of honeys. I. Introduction and results. Bee World 36, 197-206

White JW Jr (1979) Spectrophotometric method for hydroxymethylfurfural in honey. $J$ Assoc Off Anal Chem 62, 509-514

White JW Jr, Pairent FW (1959) Report on the analysis of honey. $J$ Assoc Off Agric Chem 42, 344-348

White JW Jr, Petty J, Hager RB (1958) The composition of honey. II. Lactone content. $J$ Assoc Off Agric Chem 41, 194-197

White JW Jr, Riethof ML, Subers MH, Kushnir I (1962) Composition of American honeys. Tech Bull US Dept Agric, No 1261 